\title{
PREVALENCE OF ANTIBIOTIC RESISTANCE AMONG ESCHERICHIA COLI, MEMBER OF NORMAL FECAL FLORA, ISOLATED IN CHILDREN IN TIRANA - ALBANIA
}

\author{
Denada Lacej ${ }^{13^{*}}$, Irida Ikonom Hoxha ${ }^{2}$, Majlinda Sana ${ }^{2}$, Esmeralda Meta ${ }^{4}$, Andi Koraqi ${ }^{1,3}$ \\ ${ }^{1 *}$ Laboratory of Clinical Microbiology, University Hospital Center "Mother Theresa" Tirana, Albania; \\ ${ }^{2}$ University" Alexander Moisiu” Durres, Albania; \\ ${ }^{3 *}$ Department of Microbiology at Medical University, Tirana, Albania; \\ ${ }^{4}$ Infectious Disease Service, UHC "Mother Theresa” Tirana, Albania; \\ *Corresponding Author Denada Lacej, e-mail: lacejdenada@gmail.com;
}

Received July 2020; Accepted August 2020; Published September 2020;

DOI: https://doi.org/10.31407/ijees10.320

\begin{abstract}
Antimicrobial resistance is a major matter of public health concern. The aim of this study is to determine the frequency of antibiotic resistance of E.Coli in fecal flora of healthy children in Tirana - Albania. Samples were taken from about 342 children (excluding all subjects who have been ill / taken antibiotics for the last two weeks) from the kindergartens / schools of Tirana aged 1 year to 10 years (average age 5,24 $\pm 1,44$ ). Rectal swab were plated on MacConkey agar with $10 \mathrm{mg} / \mathrm{l}$ ampicillin. Isolated resistant colonies Lac+ were identified like E. Coli (or coli - shape) and were studied further. Antibiotic resistant Escherichia Coli was present in $81(\%)$ per cent of children studied, and $32(\%)$ per cent resistance was transferable. $49 \%$ of children that not used antibiotic (with no history of antibiotic consumption) during last year, carried resistant E. Coli and transferable R plasmids were present in $28 \%$ of them. $46 \%$ of children that not frequent day/care center carried antibiotic E. Coli and transferable R plasmid were present in $20 \%$ of them. Multiple regression analysis revealed that age, fathers education's, mothers education's sex and number of children in family could be identified as an independent risk factor for the emergence of resistance in the population studies. Normal fecal flora in the population we studied seems to play an important role as reservoir of antibiotic resistance gene.
\end{abstract}

Keywords: escherichia coli, antibiotic resistance, children 